\title{
MIGRATION IMPACT AS A POSITIVE CHANGE IN TOURISM DEMAND
}

\author{
Daniel Dragičević \\ Maja Nikšić Radić \\ Suzana Herman
}

https://doi.org/10.20867/tosee.05.17

\begin{abstract}
Purpose - The purpose of this paper is to offer some insights into the future of tourism with particular consideration given to migration, and it impacts on tourism.

Methodology - Comparative method and correlation analysis were chosen to quantify possible linkages between observed variables. Obtained data were analysed with methods of descriptive statistics. Data were collected from a variety of international sources like Eurostat, UNWTO and UN DESA databases. Research results are synthesised and presented in tables and graphs.

Findings - Review of the statistical data, i.e. correlation and descriptive statistics indicated an essential relation between migration and tourism. Comparative analysis used annual data for 28 European Union countries from 1990 to 2017 while correlation analysis utilised data from 1990 to 2016. Results showed a significant correlation between tourism (nights spent) and immigration for 18 countries, which may indicate that a higher number of nights spent in accommodation services are associated with higher values of immigration.

Contribution - Paper findings are in line with conceptualising the migration-tourism relationship. The contribution of this paper lies in a new understanding of the linkages between migration and tourism. Migration represents an essential determinant of VFR tourism development. The results can help in modelling travel demand and suggesting policies that best suit the travel needs of migrant communities. Empirical results obtained from the sample of researched tourist destinations add to a better understanding of such vital research topic.
\end{abstract}

Keywords tourism, migration, VFR, tourism demand, European Union

\section{INTRODUCTION}

Visiting friends and relatives (VFR) hypothesis, which views migration as a form of boosting tourism, has effects on the social, economic and cultural development of many societies. Tourism and migration are undoubtedly a form of human mobility. Changes in directions and scales considering the tourism and migration often complement each other and replace (Bell and Ward 2000). The bond between migration and tourism is a twoway street. Residents of former homeland, which have settled down in another country, keep strong ties with their birthplace socially and emotionally. Immigrants indirectly encourage short term tourism due to visits by friends and relatives in their new country of residence. Etzo (2016) states that tourists travelling to friends and relatives, upon returning to their country will convey their travel experience to other friends, and this will most likely affect the choice of their future holiday destination. As a result, this positively affects the competitiveness of destination by increasing its tourist services and infrastructure. Observing immigrants as hosts is particularly intriguing since they have a shared context on visitor experience and the introduction of a new community. Friends 
ToSEE - Tourism in Southern and Eastern Europe, Vol. 5, pp. 205-217, 2019

D. Dragičević, M. Nikšić Radić, S. Herman: MIGRATION IMPACT AS A POSITIVE CHANGE IN ...

and relatives visiting host will most likely use this opportunity for a holiday. By looking at the locality, more immigrants mean more VFR visitors, thus strengthening cultural bonds with the origin countries which may lead to additional forms of tourist activity (Dwyer et al. 2014; Seetaram 2012).

Tourism presents one of the fastest growing activity. WTTC report for 2018 outlines a few of the benefits that tourism provides (WTTC 2018). Tourism participates with more than $10 \%$ of global GDP. The direct contribution of Tourism \& Travel to GDP grew by $4.6 \%$ in 2017 which is higher compared to the growth of the worldwide economy $(3.0 \%)$. In 2017 tourism created more than 313 million jobs (directly and indirectly employed) which represents $9.9 \%$ of total employment and one in every ten jobs worldwide. In the same year, the world generated USD 1,494.2 bn in visitor exports while international tourist arrivals grew by $7.0 \%$.

Paper is structured in the following way. Starting from the introduction, as a preface of this research, the paper follows tree sections. The first section of the literature review gives an overview of previous research by other authors on this topic. Following, the methodology and data section present the results of the observed period and comments on the main empirical findings. The last chapter concludes the paper and analyses the given recommendations.

\section{LITERATURE REVIEW}

A relationship between immigrants and tourism can be described as complex and dynamic. According to the survey made by UNWTO (2015) in 2014, approximately a quarter of international travel was due to visiting friends and relatives. Only a few tourist researchers see the potential benefits for travellers who are visiting friends and relatives. This is because it reflects on traveller decision, whether they will use the opportunity and visit multiple places or visit other friends or relatives on the same trip (Griffin and Nunkoo 2016). Griffin (2013) argues that the desire to visit friends and relatives is a fundamental driver for a large part of global tourism. Munoz et al. (2017) have stated that economic benefits reflecting on visiting friends and relative's community are consequently affecting social and cultural development. This type of tourist is using the time to go to festivals, see attractions, neighbourhoods and therefore indirectly improving the quality of life for the residents making the locality more attractive and authentic. Experiences of immigrants with intra-regional travel are important when they host VFRs (Griffin 2017). McLeod and Busser (2014), as well as Duval (2004), suggest that VFR travel should be considered an entirely different form of tourism. For Williams and Hall (2000) VFR travel is an extension of migration and tourism, while for Hall and Müller (2004) second home phenomenon linking tourism and migration indicates that these two phenomena are overlapping. Hoogendoorn (2011) argues that the reason for mobility and migration processes related to visits often arise just because of VFR travel. Due to the use of unpaid accommodation as well as the fact that marketing activities in no way affect the personal motives of VFR visitors when choosing a destination, tourism perceives the VFR as low market value (Backer 2007, 2012; Scheyvens 2007). Further, only a third of VFR passengers use commercial accommodation, but they also stay longer than other travellers (Müri and Sägesser 2003). Research of British Tourism Association 
ToSEE - Tourism in Southern and Eastern Europe, Vol. 5, pp. 205-217, 2019

D. Dragičević, M. Nikšić Radić, S. Herman: MIGRATION IMPACT AS A POSITIVE CHANGE IN ...

(ABTA 2011) has shown that since 1984 VFR tourism has been growing faster in Britain compared to other travelling opportunities or business travel. The paradox related to VFR travel is that tourism planners and academics have neglected its importance. Relationships between relatives and friends have been excavated and maintained in all places and times in a variety of ways, and this is a reflection of reality (Seaton 2017). Yousuf and Backer (2015) analysed the number of published papers on VFR topic for 1990 - 2015 period. They came across a total of 129 articles related to VFR. The results showed that in the last five analysed years the interest in the subject of VRF has grown.

Table 1: Empirical findings of previous studies

\begin{tabular}{|c|c|c|c|c|}
\hline $\begin{array}{c}\text { List of } \\
\text { researchers }\end{array}$ & $\begin{array}{c}\text { Case } \\
\text { study and } \\
\text { period }\end{array}$ & Variables & Methodology & Results \\
\hline $\begin{array}{l}\text { Massidda } \\
\text { and Piras } \\
(2015)\end{array}$ & $\begin{array}{l}20 \text { Italian } \\
\text { regions; } \\
1987-2010\end{array}$ & $\begin{array}{l}\text { Domestic bed nights, } \\
\text { migration stocks, } \\
\text { relative prices, } \\
\text { consumer price index } \\
\text { deflator, real per capita } \\
\text { gross domestic product } \\
\text { at destination }\end{array}$ & $\begin{array}{l}\text { Panel data } \\
\text { analysis }\end{array}$ & $\begin{array}{l}\text { A strong, positive } \\
\text { relationship } \\
\text { between domestic } \\
\text { tourism and } \\
\text { internal migration } \\
\text { in Italy }\end{array}$ \\
\hline $\begin{array}{l}\text { Massidda et } \\
\text { al. }(2015)\end{array}$ & $\begin{array}{l}65 \\
\text { countries; } \\
2005-2011\end{array}$ & $\begin{array}{l}\text { TOT, VFR, NON- } \\
\text { VFR, Bussines } \\
\text { Holiday, M_ita, M_for, } \\
\text { P, GDP, DIST, CONT, } \\
\text { CRT }\end{array}$ & $\begin{array}{l}\text { Panel data } \\
\text { analysis }\end{array}$ & $\begin{array}{l}\text { A stock of Italian } \\
\text { residing abroad } \\
\text { has a positive } \\
\text { impact on } \\
\text { outbound tourism }\end{array}$ \\
\hline $\begin{array}{l}\text { Forsyth et al. } \\
\text { (2012) }\end{array}$ & $\begin{array}{l}\text { Australia, } \\
2006\end{array}$ & $\begin{array}{l}\text { GDP, real value added, } \\
\text { economic welfare, } \\
\text { employment, number } \\
\text { of arrivals/departures, } \\
\text { migration elasticity, } \\
\text { arrivals after an } \\
\text { increase in migration, } \\
\text { migration induced } \\
\text { change in arrivals, } \\
\text { expenditure per trip, } \\
\text { total expenditure }\end{array}$ & $\begin{array}{l}\text { Computable } \\
\text { general } \\
\text { equilibrium } \\
\text { (CGE) model }\end{array}$ & $\begin{array}{l}\text { Both migration } \\
\text { induced total and } \\
\text { VFR tourism } \\
\text { have economic } \\
\text { impacts on a } \\
\text { destination }\end{array}$ \\
\hline $\begin{array}{l}\text { Dwyer et al. } \\
(2014)\end{array}$ & $\begin{array}{l}\text { Australia; } \\
\text { 1991-2006 }\end{array}$ & $\begin{array}{l}\text { Income, relative price, } \\
\text { migration number, } \\
\text { average migration } \\
\text { years in Australia, the } \\
\text { population in origin } \\
\text { countries, GDP per } \\
\text { capita, number of } \\
\text { short-term travel flows }\end{array}$ & $\begin{array}{l}\text { Ordinary Least } \\
\text { Square (OLS) }\end{array}$ & $\begin{array}{l}\text { A robust } \\
\text { quantitative link } \\
\text { between } \\
\text { migration and } \\
\text { VFR tourism }\end{array}$ \\
\hline $\begin{array}{l}\text { Leitão and } \\
\text { Shahbaz } \\
\text { (2012) }\end{array}$ & $\begin{array}{l}\text { Portugal; } \\
\text { 1995-2008 }\end{array}$ & $\begin{array}{l}\text { Total number of visits, } \\
\text { population, GDP per } \\
\text { capita, migrant stock, } \\
\text { VFR }\end{array}$ & $\begin{array}{l}\text { Dynamic panel } \\
\text { data approach }\end{array}$ & $\begin{array}{l}\text { There is a } \\
\text { positive } \\
\text { correlation } \\
\text { between } \\
\text { immigration and } \\
\text { tourism demand }\end{array}$ \\
\hline
\end{tabular}


ToSEE - Tourism in Southern and Eastern Europe, Vol. 5, pp. 205-217, 2019

D. Dragičević, M. Nikšić Radić, S. Herman: MIGRATION IMPACT AS A POSITIVE CHANGE IN ...

\begin{tabular}{|c|c|c|c|c|}
\hline $\begin{array}{c}\text { List of } \\
\text { researchers }\end{array}$ & $\begin{array}{c}\text { Case } \\
\text { study and } \\
\text { period }\end{array}$ & Variables & Methodology & Results \\
\hline $\begin{array}{l}\text { Provenzano } \\
\text { and Baggio } \\
(2017)\end{array}$ & $\begin{array}{l}\text { EU28 } \\
\text { member } \\
\text { states; } \\
\text { 2000-2012 }\end{array}$ & $\begin{array}{l}\text { Tourism flows from } \\
\text { country and to country, } \\
\text { GDP PPP, the distance } \\
\text { between two countries }\end{array}$ & $\begin{array}{l}\text { Complex } \\
\text { network } \\
\text { analysis and } \\
\text { gravity model }\end{array}$ & $\begin{array}{l}\text { Results suggest } \\
\text { that the higher the } \\
\text { stock of } \\
\text { immigrants in a } \\
\text { country, the } \\
\text { higher the flow of } \\
\text { incoming tourists }\end{array}$ \\
\hline Etzo (2016) & $\begin{array}{l}\text { Japan } \\
\text { 2000-2013 }\end{array}$ & $\begin{array}{l}\text { Number of foreign } \\
\text { citizens residing in } \\
\text { Japan, the number of } \\
\text { Japanese living abroad, } \\
\text { GDP per capita, real } \\
\text { exchange rate, CPI, the } \\
\text { nominal exchange rate } \\
\text { between Japan and } \\
\text { source country }\end{array}$ & $\begin{array}{l}\text { Dynamic panel } \\
\text { data }\end{array}$ & $\begin{array}{l}\text { An increase in } \\
\text { immigration in } \\
\text { Japan is likely to } \\
\text { boost inbound } \\
\text { tourism arrivals } \\
\text { and rise the } \\
\text { positive } \\
\text { economic effects } \\
\text { related to the } \\
\text { tourism sector }\end{array}$ \\
\hline
\end{tabular}

Source: Authors research

Table 1 indicates differences and similarities of empirical studies which arise from research area (country), covered period, variables and methodology used. Massidda and Piras (2015) investigated the impact of migration on domestic tourism in Italy. The panel analysis was developed within the framework of standard tourist demand in which the number of internal migrants in a particular region is considered an attractive factor for tourist flows from the rest of the country. Results show a strong positive correlation between domestic tourist nights per capita and the number of internal migrations per capita. Similar conclusions hold for Italian international tourism. Massidda et al. (2015) paper concluded that the percentage of Italians living abroad positively influence outbound tourism for all purposes. Population born abroad who live in Italy promotes Italian tourism business by motivating for visiting friends and relatives, but not for vacation. Dwyer et al. (2014) investigated the relationship between tourism and migration in Australia for the 1980 - 2009 period. The results confirmed a robust quantitative relationship between migration and VFR tourism and also indicated a substantial mutual link between migration and other forms of tourism. Increasing migration by $10 \%$ increases the input of VFR flow by $4.9 \%$ in 1991 and $6.6 \%$ in 2006. Immigration is a decisive determinant of tourism demand (Etzo 2016; Leitão and Shahbaz 2012) indicating more the immigrants in the country greater the flow of incoming tourists (Provenzano and Baggio 2017). The positive influence of immigration (Etzo et al. 2013) is not only limited to GDP, inbound and outbound demand (Forsyth et al. 2012) but it has positive effects on tourist companies (Massidda et al. 2017). Tourism itself can be viewed, in a broader context, as a seasonal migration (Haug et al. 2007).

There is a prominent difference between segments motivating a visit to a friend (VF) and visits to relatives (VR) (Backer et al. 2017). Research shows that the VF tourists (independent variable) longer hold back, actively participate in activities in free time and positively influence the development of the tourist experience. Another variable, VR represents the tourists who are entirely passive during the visit and focused solely on 
ToSEE - Tourism in Southern and Eastern Europe, Vol. 5, pp. 205-217, 2019

D. Dragičević, M. Nikšić Radić, S. Herman: MIGRATION IMPACT AS A POSITIVE CHANGE IN ...

social activity and linkages therefore adversely affect the formulation of tourist experience (Zátori et al. 2017).

\section{DATA AND METHODOLOGY}

This paper analyses the interdependence between immigration and tourism. For this purpose, authors have chosen European Union countries (EU 28) to test whether there is any statistically significant correlation between immigration and tourism. States in text are aggregated to areas in the following manner: Eastern Europe - Bulgaria (BGR), Czech Republic (CZE), Hungary (HUN), Poland (POL), Romania (ROU), Slovakia (SVK); Northern Europe - Denmark (DNK), Estonia (EST), Finland (FIN), Ireland (IRL), Latvia (LVA), Lithuania (LTU), Sweden (SWE), United Kingdom (GBR); Southern Europe - Croatia (HRV), Cyprus (CYP), Greece (GRC), Italy (ITA), Malta (MLT), Portugal (PRT), Slovenia (SVN), Spain (ESP); Western Europe - Austria (AUT), Belgium (BEL), France (FRA), Germany (DEU), Luxembourg (LUX), Netherlands (NLD). Country abbreviations used ISO ALPHA-3 Code, where applicable. The comparative analysis employed annual data from 1990 to 2017 while correlation analysis utilised data from 1990 to 2016. Nights spent at tourist accommodation establishments were used as a proxy for tourism demand due to data limitation. This variable relates to all commercial accommodation services (NACE_R2, I551-I553). Tourism data for comparative analysis is based on total nights spent while correlation analysis on inbound nights spent $(n)$. These variables were obtained from Eurostat (Eurostat, n.d.) and UNWTO database (UNWTO, n.d.). Inbound tourism is defined as "activities of a non-resident visitor within the country of reference on an inbound tourism trip" (UNWTO 2017, 13).

Immigration data ( $\mathrm{im}$ ) for European countries were taken from Eurostat. Eurostat defines immigration as "the action by which a person establishes his or her usual residence in the territory of a Member State for a period that is, or is expected to be, of at least 12 months, having previously been usually resident in another Member State or a third country" (OJEU 2007). This research also used world data for the international migrant stock from the United Nations Department of Economic and Social Affairs, Population Division (UNDESA 2017a). UN DENSA defines international migrant stock as "the total number of international migrants present in a given country at a particular point in time" (UNDESA 2017b, 9) and international migrant as "any person who changes his or her country of usual residence" (UNDESA 1998, 9). 
ToSEE - Tourism in Southern and Eastern Europe, Vol. 5, pp. 205-217, 2019

D. Dragičević, M. Nikšić Radić, S. Herman: MIGRATION IMPACT AS A POSITIVE CHANGE IN ...

\section{RESULTS}

Tourism data for European countries show a continuous growing trend in the number of total nights spent in all commercial accommodation establishments.

Table 2: Total nights spent in European regions from 1990 to 2017 (in millions)

\begin{tabular}{|c|c|c|c|c|c|}
\hline Year & $\begin{array}{c}\text { Eastern } \\
\text { Europe }\end{array}$ & $\begin{array}{c}\text { Northern } \\
\text { Europe }\end{array}$ & $\begin{array}{c}\text { Southern } \\
\text { Europe }\end{array}$ & $\begin{array}{c}\text { Western } \\
\text { Europe }\end{array}$ & EU 28 \\
\hline 1990 & 108 & 327 & 445 & 658 & 1,538 \\
\hline 1995 & 123 & 358 & 586 & 699 & 1,767 \\
\hline 2000 & 150 & 396 & 842 & 782 & 2,171 \\
\hline 2005 & 154 & 410 & 874 & 848 & 2,286 \\
\hline 2010 & 154 & 351 & 936 & 938 & 2,378 \\
\hline 2015 & 203 & 618 & 1,077 & 1,046 & 2,944 \\
\hline 2017 & 236 & 132 & 1,200 & 1,109 & 2,677 \\
\hline
\end{tabular}

Note: No available data for FRA 1996-1997, HRV 1990-1992, EST 1990-2001, GRC 1990-1993, HUN 1990-1992, IRL 1990-1993 and 2017, LVA 1990-1994, LTU 1990-1993, MLT 1990-2002, POL 1991 and 1993-1994, GBR 2014, 2017

Source: UNWTO, Eurostat

From 1990 to 2017 overall structure of total nights spent has changed.

Figure 1: Average annual growth rate of total nights spent in European regions

$10 \%$

$5 \%$

$0 \%$

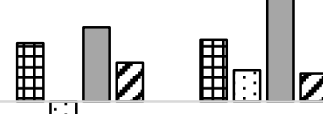

19 : 2017

$-\square \sqcap$

2000-2009

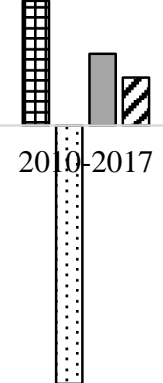

$-5 \%$

$-10 \%$

$-15 \%$

$\boxplus$ Eastern Europe $\square$ Northern Europe $\square$ Southern Europe $\square$ Western Europe

Source: Authors' calculations 
ToSEE - Tourism in Southern and Eastern Europe, Vol. 5, pp. 205-217, 2019

D. Dragičević, M. Nikšić Radić, S. Herman: MIGRATION IMPACT AS A POSITIVE CHANGE IN ...

In 1990 Eastern Europe participated with $7.0 \%$, Northern with $21.2 \%$, Southern with $28.9 \%$ and Western with $42.8 \%$ of total nights spent in EU 28. A shift in 2017 structure was mainly towards Southern and Eastern Europe (Eastern Europe 8.8\%, Northern Europe 4.9\%, Southern Europe 44.8\% and Western Europe 41.4\%). The average annual growth rate of nights spent, from 1990 to 2017, in EU 28 was 2.1\% (Figure 1). The highest growth rate was observed in Southern Europe (3.7\%) and the lowest in Western Europe $(1.9 \%)$. Northern Europe had an average decline rate of $-3.3 \%$. Among the countries, Lithuania and Croatia had an impressive average annual growth rate $(14.9 \%$ and $12.8 \%$ respectively) for the $2010-2017$ period, while the lowest growth rate was realised in France (1.5\%).

Criteria for choosing the European Union (EU 28) as a geographical area for conducting correlation analysis was a high percentage of overall world migration. Table 3 indicates that in 2017 Europe constitutes $30.2 \%$ of the total world`s international migration stock. Asia is the only region with a higher percentage of migration stock $(30.9 \%)$.

Table 3: International migrant stock at mid-year for the period 1990 - 2017 (in millions)

\begin{tabular}{|c|c|c|c|c|c|c|c|}
\hline \multirow{2}{*}{$\begin{array}{l}\text { Region, area of } \\
\text { destination }\end{array}$} & \multicolumn{7}{|c|}{ Year } \\
\hline & 1990 & 1995 & 2000 & 2005 & 2010 & 2015 & 2017 \\
\hline WORLD & 152.5 & 160.7 & 172.6 & 190.5 & 220.0 & 247.6 & 257.7 \\
\hline High-income countries & 75.2 & 86.6 & 100.4 & 117.8 & 141.8 & 156.8 & 164.8 \\
\hline $\begin{array}{l}\text { Middle-income } \\
\text { countries }\end{array}$ & 68.5 & 64.4 & 64.0 & 64.7 & 70.2 & 79.8 & 81.4 \\
\hline Low-income countries & 8.5 & 9.3 & 7.7 & 7.6 & 7.5 & 10.5 & 10.9 \\
\hline AFRICA & 15.7 & 16.4 & 14.8 & 15.5 & 17.0 & 23.4 & 24.7 \\
\hline ASIA & 48.1 & 46.4 & 49.2 & 53.2 & 65.9 & 76.6 & 79.6 \\
\hline EUROPE & 49.2 & 52.9 & 56.3 & 63.2 & 70.7 & 74.5 & 77.9 \\
\hline $\begin{array}{l}\text { LATIN AMERICA } \\
\text { AND THE } \\
\text { CARIBBEAN }\end{array}$ & 7.2 & 6.7 & 6.6 & 7.2 & 8.2 & 9.3 & 9.5 \\
\hline $\begin{array}{l}\text { NORTHERN } \\
\text { AMERICA }\end{array}$ & 27.6 & 33.3 & 40.4 & 45.4 & 51.0 & 55.8 & 57.7 \\
\hline OCEANIA & 4.7 & 5.0 & 5.4 & 6.0 & 7.1 & 8.1 & 8.4 \\
\hline
\end{tabular}

Source: UN DESA

Migrants prefer high-income countries as their final destinations $(59.3 \%$ of overall migration stock). Wahba (2015) also claims that developed countries host a significant number of world migrants: 40 million in the US, 10 million in Germany, and 7 million each in Canada, France, and the UK. Migrations from low to high-income countries are caused by real income differential, differences in medical treatment, police strength, political instability (Narayan and Smyth 2016). The average annual growth rate of international migration stock in high-income countries, for 1990 - 2017 period, was very high $(2.9 \%)$ compared to low and middle-income countries $(0.9 \%$ and $0.6 \%$ respectively). Increased immigration to high-income countries is beneficial to 
ToSEE - Tourism in Southern and Eastern Europe, Vol. 5, pp. 205-217, 2019

D. Dragičević, M. Nikšić Radić, S. Herman: MIGRATION IMPACT AS A POSITIVE CHANGE IN ...

destinations as a response to ageing and fertility decline trend, especially in rural areas (Hugo and Morén-Alegret 2008). A rise in the share of international migrants can lead to a decline in the percentage of people living on less than 1 USD per person per day (Adams JR. and Page 2005). At the same time increment of the remittances per capita to departing states lead to a decline in poverty headcount, poverty depth and poverty severity (Peković 2017).

Detail analysis of European regions reveals Western Europe as the destination with the highest percentage of immigrants. In 2016 43.7\% of all immigrants were in Western Europe, and this is in line with world statistics regarding worlds migration stock (high percentage in high-income countries).

Table 4: Immigration statistics in European regions from 1990 to 2016

\begin{tabular}{|l|r|r|r|r|r|}
\hline \multicolumn{1}{|c|}{ Year } & \multicolumn{1}{c|}{$\begin{array}{c}\text { Eastern } \\
\text { Europe }\end{array}$} & \multicolumn{1}{c|}{$\begin{array}{c}\text { Northern } \\
\text { Europe }\end{array}$} & $\begin{array}{c}\text { Southern } \\
\text { Europe }\end{array}$ & $\begin{array}{c}\text { Western } \\
\text { Europe }\end{array}$ & EU 28 \\
\hline 1990 & 3,570 & 162,065 & 207,795 & $1,446,543$ & $1,819,973$ \\
\hline 1995 & 37,151 & 164,115 & 322,398 & $1,265,434$ & $1,789,098$ \\
\hline 2000 & 31,331 & 558,264 & 795,411 & $1,156,837$ & $2,541,843$ \\
\hline 2005 & 102,754 & 255,958 & $1,144,354$ & $1,061,321$ & $2,564,387$ \\
\hline 2010 & 384,124 & 831,996 & 956,341 & $1,061,163$ & $3,233,624$ \\
\hline 2015 & 471,108 & $1,000,744$ & 775,779 & $2,411,693$ & $4,659,324$ \\
\hline 2017 & 492,385 & 989,800 & 927,411 & $1,873,298$ & $4,282,894$ \\
\hline
\end{tabular}

Note: No available data for FRA 1990-2005; HRV 1990, 2000 and 2005; AUT 1990- 1995; BEL 2008-2009; BGR 1990-2006, 2008-2011; CYP 1990-1997; CZE 1990-1994, 1998-2000; EST 1990-1999; GRC 1990; HUN 1990-1994; LVA 1990; MLT 1990-2004; PRT 1990; ROU 1990-2007; GBR 1990-1997, 2005

Source: Eurostat

The highest average annual growth rate of immigration, for 2010 - 2016 period, was attained in Western Europe $(9.9 \%)$ followed by Eastern $(4.2 \%)$ and Northern Europe (2.9\%). Southern Europe had an average decline of $-0.5 \%$

The further analysis applied correlation analysis to see whether there is an interdependence between variables inbound nights spent in all commercial accommodation establishments $(n)$ and immigration $(\mathrm{im})$. Due to data limitation variables take annual values. Nights spent data (tourism demand proxy) was chosen as a dependent variable while immigration data as an independent. The null $\left(H_{o}\right)$ hypothesis is $H_{0}: \rho_{x y}=0$ and alternative $H_{1}: \rho_{x y} \neq 0$.

Pearson`s correlation assessed the relationship between nights spent and immigration for all 28 European countries. Overall (available) $\mathrm{N}$ varied from country to country ranging from 11 to 27. Statistically significant correlation was obtained for 18 states. Due to space limit table 5 and 6 indicate only significant correlation coefficients. Table 5 reveals the results for Northern and Western European countries. A medium positive correlation was determined for one Western (AUT) and two Northern European countries (EST and 
ToSEE - Tourism in Southern and Eastern Europe, Vol. 5, pp. 205-217, 2019

D. Dragičević, M. Nikšić Radić, S. Herman: MIGRATION IMPACT AS A POSITIVE CHANGE IN ...

GBR) with strong evidence against $H_{0}$ (no correlation), at $\mathrm{p}<0.01$ (GBR) and $\mathrm{p}<0.05$ (EST and AUT). A strong positive correlation between nights and immigration was obtained for France, Belgium, Finland, Latvia, Lithuania, Netherlands and Sweden. This might indicate that a higher number of nights spent in accommodation establishments are associated with higher values of immigration.

Similar results were found for Eastern and Southern European counties. A medium positive correlation was established for Slovakia, $r(25)=0.405$ with significant evidence against $H_{0}$ (no correlation), at $\mathrm{p}<0.05$. A strong positive correlation was calculated for Spain, Hungary, Italy, Malta, Poland and Slovenia while strong negative for Croatia.

Table 5: Correlation coefficients between nights spent and immigration in Western and Northern European countries

\begin{tabular}{|c|c|c|c|c|c|c|c|c|c|c|}
\hline & n_FRA & n_AUT & n_BEL & n_EST & n_FIN & n_LVA & n_LTU & n_NLD & n_SWE & n_GBR \\
\hline im_FRA & $\begin{array}{l}0.770 * * * \\
(0.006)\end{array}$ & & & & & & & & & \\
\hline im_AUT & & $\begin{array}{l}0.532 * * \\
(0.013)\end{array}$ & & & & & & & & \\
\hline im_BEL & & & $\begin{array}{l}0.858 * * * \\
(0.000)\end{array}$ & & & & & & & \\
\hline im_EST & & & & $\begin{array}{l}0.586 * * \\
(0.022)\end{array}$ & & & & & & \\
\hline im_FIN & & & & & $\begin{array}{l}0.913 * * * \\
(0.000)\end{array}$ & & & & & \\
\hline im_LVA & & & & & & $\begin{array}{l}0.758 * * * \\
(0.000)\end{array}$ & & & & \\
\hline im_LTU & & & & & & & $\begin{array}{l}0.969 * * * \\
(0.000)\end{array}$ & & & \\
\hline im_NLD & & & & & & & & $\begin{array}{l}0.705^{* * *} * \\
(0.000)\end{array}$ & & \\
\hline im_SWE & & & & & & & & & $\begin{array}{l}0.860 * * * \\
(0.000)\end{array}$ & \\
\hline im_GBR & & & & & & & & & & $\begin{array}{l}0.522 * * \\
(0.038)\end{array}$ \\
\hline $\mathrm{N}$ & 11 & 21 & 25 & 15 & 27 & 22 & 23 & 27 & 27 & 16 \\
\hline
\end{tabular}

p-values in parentheses

$* \mathrm{p}<0.10 * * \mathrm{p}<0.05 * * * \mathrm{p}<0.01$

Note: $\mathrm{n}_{-}$- inbound nights spent in all commercial accommodation services; im_

Source: Authors' calculations 
ToSEE - Tourism in Southern and Eastern Europe, Vol. 5, pp. 205-217, 2019

D. Dragičević, M. Nikšić Radić, S. Herman: MIGRATION IMPACT AS A POSITIVE CHANGE IN ...

Table 6: Correlation coefficients between nights spent and immigration in Eastern and Southern European countries

\begin{tabular}{|c|c|c|c|c|c|c|c|c|}
\hline & n_ESP & n_HRV & n_HUN & n_ITA & n_MLT & n_POL & n_SVK & n_SVN \\
\hline$\overline{\text { im_ESP }}$ & $\begin{array}{l}0.697 * * * \\
(0.000)\end{array}$ & & & & & & & \\
\hline im_HRV & & $\begin{array}{l}-0.738 * * * \\
(0.000)\end{array}$ & & & & & & \\
\hline im_HUN & & & $\begin{array}{l}0.670 * * * \\
(0.001)\end{array}$ & & & & & \\
\hline im_ITA & & & & $\begin{array}{l}0.673 * * * \\
(0.000)\end{array}$ & & & & \\
\hline im_MLT & & & & & $\begin{array}{l}0.861^{* * *} \\
(0.000)\end{array}$ & & & \\
\hline im_POL & & & & & & $\begin{array}{l}0.784 * * * \\
(0.000)\end{array}$ & & \\
\hline im_SVK & & & & & & & $\begin{array}{l}0.405^{* *} * \\
(0.036)\end{array}$ & \\
\hline im_SVN & & & & & & & & $\begin{array}{l}0.617 * * * \\
(0.001)\end{array}$ \\
\hline $\mathrm{N}$ & 27 & 22 & 22 & 27 & 12 & 24 & 27 & 27 \\
\hline
\end{tabular}

p-values in parentheses

$* \mathrm{p}<0.10 * * \mathrm{p}<0.05 * * * \mathrm{p}<0.01$

Note: $\mathrm{n}_{-}$- inbound nights spent in all commercial accommodation services; im_

Source: Authors' calculations

Results of correlation analysis are in line with the research of Dwyer et al. (2014) who also confirmed a strong quantitative relationship between migration and VFR tourism in Australia and showed a strong and mutual link between migration and other forms of tourism. Their study indicated that an increase of $10 \%$ in migration would produce an additional 5,49\% in VFR outbound flows. Similarly, Leitão and Shahbaz (2012) determined a positive correlation between immigration and tourism demand for Portugal. GPD per capita and population, which determines the ability to travel, are explanatory variables and they have a positive impact on VFR visit. Provenzano and Baggio (2017) results', for EU 28, suggest that the higher the stock of immigrants in the country, the higher the flow of incoming tourist. Authors argued that this positive contribution to tourism is mainly due to the mobility of VFR because of the link between VFR travel and migration. Results` of Etzo (2016) study for Japan reveal the stock of immigrants as an essential exogenous variable of inbound tourism flows. The positive effect is higher for "holiday" than for "business" arrivals.

\section{CONCLUSION}

Tourism data for European countries show a continuous growing trend in the number of total nights spent in all commercial accommodation establishments. The VFR type of trip is dominant in the global market presenting the future of tourism, and at the same time, the economic impact of VFR tourism is much higher than commonly thought.

This study has confirmed that migration is an essential factor of VFR tourism and that the relationship between tourism demand and migration is progressively growing. This paper analysed the relationship between nights spent and immigration using comparative and correlation analysis. Results of this study supported the hypothesis that there is a 
ToSEE - Tourism in Southern and Eastern Europe, Vol. 5, pp. 205-217, 2019

D. Dragičević, M. Nikšić Radić, S. Herman: MIGRATION IMPACT AS A POSITIVE CHANGE IN ...

positive correlation between immigration and tourism demand. Pearson`s correlation assessed a relationship between nights spent and immigration for all 28 European countries, and statistically significant correlation was found for 18 countries. A medium positive correlation was determined for one Western (AUT), two Northern (EST and GBR) and one Eastern European (SVK) countries. A strong positive correlation between nights and immigration was shown for three Western (FRA, BEL, NLD), four Northern (FIN, LVA, LTU, SWE), two Eastern (HUN, POL) and four Southern European countries (ESP, ITA, MLT, SVN). A strong negative correlation was recorded only for Croatia. The reason for the strong negative correlation could be explained through its geographical position as the country of transit at the time of immigration wave. The results of this paper are in line with the research conducted for Australia (Dwayer et al. 2014), Portugal (Leitão and Shahbaz 2012), EU 28 (Provenzano and Baggio 2017) and Italy (Massidda and Piras 2015). The established positive effect of migration on tourism is especially significant in the age where migration could be perceived as one of the conduits for terrorist attacks. Immigrant communities enrich local cultural diversity and through side-trips with VFR guests add additional context to tourist destinations (Griffin 2017).

Research has a few limitations such as insufficient or low number of observations and aggregation of data. Under a broader perspective, results can be interpreted as evidence in favour of a positive impact of immigration on tourism demand. Considering the upsurge of migration flows, the empirical evidence provided in this paper should be carefully considered by national policymakers when designing their policies. Future analysis should be done concerning the disaggregation of inbound tourism data by matching the nationality of incoming tourists and immigration statistics.

\section{ACKNOWLEDGEMENTS}

This work was supported by the University of Rijeka under Grant ZP UNIRI 8/18

\section{REFERENCES}

ABTA (2011), ABTA Travel Trends Report 2011 [Online]. https://www.onecaribbean.org/content/files/ABTA2011TravelTrendsReport.pdf (Accessed 15 January 2019).

Backer, E. (2007), "VFR travel: An examination of the expenditures of VFR travellers and their hosts", Current Issues in Tourism, Vol. 10, No. 4, pp. 366-377. https://doi.org/10.2167/cit277.0.

Backer, E. (2012), "VFR travel: It is underestimated", Tourism Management, Vol. 33, No. 1, pp. 74-79. https://doi.org/10.1016/j.tourman.2011.01.027.

Backer, E., Leisch, F. and Dolnicar, S. (2017), "Visiting friends or relatives?", Tourism Management, Vol. 60, pp. 56-64. https://doi.org/10.1016/j.tourman.2016.11.007.

Bell, M. and Ward, G. (2000), "Comparing temporary mobility with permanent migration", Tourism Geographies, Vol. 2, No. 1, pp. 87-107. https://doi.org/10.1080/146166800363466.

Duval, D.T. (2004), "Linking return visits and return migration among Commonwealth Eastern Caribbean migrants in Toronto", Global networks, Vol. 4, No. 1, pp. 51-67. https://doi.org/10.1111/j.1471-0374.2004.00080.x.

Dwyer, L., Seetaram, N., Forsyth, P. and King, B. (2014), "Is the migration-tourism relationship only about VFR?", Annals of Tourism Research, Vol. 46, pp. 130-143. https://doi.org/10.1016/j.annals.2014.03.009. 
ToSEE - Tourism in Southern and Eastern Europe, Vol. 5, pp. 205-217, 2019

D. Dragičević, M. Nikšić Radić, S. Herman: MIGRATION IMPACT AS A POSITIVE CHANGE IN ...

Etzo, I. (2016), The impact of migration on tourism demand: evidence from Japan [Online]. https://mpra.ub.uni-muenchen.de/72457/1/MPRA_paper_72457.pdf (Accessed 7 December 2018).

Etzo, I., Massidda, C. and Piras, R. (2013), Estimating the Migration-Tourism Nexus for Italy's International Outbound Tourism [Online]. http://www.siecon.org/online/wp-content/uploads/2013/09/EtzoMassidda-Piras.pdf (Accessed 7 December 2018).

Eurostat (n.d.), Eurostat database, viewed 3 February 2019, http://ec.europa.eu/eurostat/data/database.

Forsyth, P., Dwyer, L., Seetaram, N. and King, B. (2012), "Measuring the economic impact of migrationinduced tourism", Tourism analysis, Vol. 17, No. 5, pp. 559-571. https://doi.org/10.3727/108354212x13485873913769.

Griffin, T. (2013), "Research note: A content analysis of articles on visiting friends and relatives tourism, 19902010”, Journal of Hospitality Marketing \& Management, Vol. 22, No. 7, pp. 781-802. https://doi.org/10.1080/19368623.2012.708960.

Griffin, T. (2017), "Immigrant hosts and intra-regional travel”, Tourism Geographies, Vol. 19, No. 1, pp. 44 62. https://doi.org/10.1080/14616688.2016.1169314

Griffin, T. and Nunkoo, R. (2016), "Paid accommodation use of international VFR multi-destination travellers", Tourism Review, Vol. 71, No. 2, pp. 90-104. https://doi.org/10.1108/tr-09-2015-0041.

Hall, C.M. and Müller, D.K. (2004), "Introduction: Second Homes, Curse or Blessing? Revisited", in Hall, Colin Michael and Müller, Dieter K (ed), Tourism, mobility, and second homes: between elite landscape and common ground, Channel View Publications, Vol. 15, pp. 3-15.

Haug, B., Dann, G.M.S. and Mehmetoglu, M. (2007), "Little Norway in Spain: From tourism to migration", Annals of Tourism Research, Vol. 34, No. 1, pp. 202-222. https://doi.org/10.1016/j.annals.2006.07.011.

Hoogendoorn, G. (2011), "Low-income earners as second home tourists in South Africa?", Tourism Review International, Vol. 15, No. 1-2, pp. 37-50. https://doi.org/10.3727/154427211x13139345020219.

Leitão, N. C. and Shahbaz, M. (2012), "Migration and tourism demand", Theoretical and Applied Economics, Vol. 19, No. 2, pp. 39-48 [Online]. http://store.ectap.ro/articole/687.pdf.

Massidda, C., Etzo, I. and Piras, R. (2015), "Migration and inbound tourism: an Italian perspective", Current Issues in Tourism, Vol. 18, No. 12, pp. 1152-1171. https://doi.org/10.1080/13683500.2014.912206.

Massidda, C., Etzo, I. and Piras, R. (2017), "The relationship between immigration and tourism firms", Tourism Economics, Vol. 23, No. 8, pp. 1537-1552. https://doi.org/10.1177/1354816617708660.

Massidda, C. and Piras, R. (2015), "Does internal migration affect Italian domestic tourism? A panel data analysis", Tourism Economics, Vol. 21, No. 3, pp. 581-600. https://doi.org/10.5367/te.2013.0362.

McLeod, B. and Busser, J.A. (2014), "Second homeowners hosting friends and relatives", Annals of Leisure Research, Vol. 17, No. 1, pp. 86-96. https://doi.org/10.1080/11745398.2014.888955.

Munoz, J.R., Griffin, T. and Humbracht, M. (2017), "Towards a new definition for "visiting friends and relatives"”, International Journal of Tourism Research, Vol. 19, No. 5, pp. 477-485. https://doi.org/10.1002/jtr.2110.

Müri, F. and Sägesser, A. (2003), "Is VFR an independent target group? The case of Switzerland", Tourism Review, Vol. 58, No. 4, pp. 28-34. https://doi.org/10.1108/eb058421.

Narayan, P.K. and Smyth, R. (2006), "What determines migration flows from low-income to high-income countries? An empirical investigation of Fiji-US migration 1972-2001," Contemporary Economic Policy, Vol. 24, No. 2, pp. 332-342. https://doi.org/10.1093/cep/byj019.

Official Journal of the European Union (2007), Regulation (EC) No 862/2007 on Migration and international protection [Online]. https://eur-lex.europa.eu/legal-content/EN/TXT/HTML/?uri=CELEX:32007 R0862\&qid=1448964364407\&from=EN (Accessed 12 January 2019).

Peković, D. (2017), "The effects of remittances on poverty alleviation in transition countries", Journal of International Studies, Vol. 10, No. 4, pp. 37-46. https://doi.org/10.14254/2071-8330.2017/10-4/2

Provenzano, D. and Baggio, R. (2017), "The contribution of human migration to tourism: The VFR travel between the EU 28 member states", International Journal of Tourism Research, Vol. 19, No. 4, pp. 412-420. https://doi.org/10.1002/jtr.2127.

Scheyvens, R. (2007), "Poor cousins no more: valuing the development potential of domestic and diaspora tourism”, Progress in Development Studies, Vol. 7, No. 4, pp. 307-325. https://doi.org/ 10.1177/146499340700700403.

Seaton, T. (2017), "Qualitative Approaches to the Phenomenology of VFR Travel: The use of Literary and Cultural Texts as Resources", International Journal of Tourism Research, Vol. 19, No. 4, pp. 455465. https://doi.org/10.1002/jtr.2100.

Seetaram, N. (2012), "Immigration and international inbound tourism: Empirical evidence from Australia", Tourism Management, Vol. 33, No. 6, pp. 1535-1543. https://doi.org/10.1016/j.tourman.2012.02.010. 
ToSEE - Tourism in Southern and Eastern Europe, Vol. 5, pp. 205-217, 2019

D. Dragičević, M. Nikšić Radić, S. Herman: MIGRATION IMPACT AS A POSITIVE CHANGE IN ...

UNDESA (1998), Recommendations on Statistics of International Migration: Revision 1 [Online]. https://unstats.un.org/unsd/publication/SeriesM/SeriesM_58rev1E.pdf (Accessed 12 January 2019).

UNDESA (2017a), Trends in International Migrant Stock: the 2017 Revision [Online] http://www.un.org/en/development/desa/population/migration/data/estimates2/data/UN_MigrantS tockTotal_2017.xlsx (Accessed 25 January 2019).

UNDESA (2017b) Handbook on Measuring International Migration through Population Censuses [Online] https://unstats.un.org/unsd/statcom/48th-session/documents/BG-4a-Migration-Handbook-E.pdf (Accessed 6 January 2019).

UNWTO (2015), UNWTO Tourism Highlights: 2015 Edition, [Online]. https://doi.org/10.18111/9789284416899 (Accessed 21 December 2018).

UNWTO (2017), Methodological Notes to the Tourism Statistics Database: 2017 Edition, Madrid, Spain [Online]. https://www.e-unwto.org/doi/pdf/10.18111/9789284418541 (Accessed 12 January 2019).

UNWTO (n.d.) UNWTO / Tourism Statistics [Online]. https://www.e-unwto.org/toc/unwtotfb/current (Accessed 2 February 2019).

Wahba, J. (2015), "Who benefits from return migration to developing countries?", IZA World of Labor: Evidence-based policy making, No. 123, pp. 1-10. https://doi.org/10.15185/izawol.123.

Williams, A.M. and Hall, C.M. (2000), "Tourism and migration: new relationships between production and consumption", Tourism geographies, Vol. 2, No. 1, pp. 5-27. https://doi.org/10.1080/146166800363420.

WTTC (2018), Travel \& Tourism Economic Impact 2018 World, [Online]. https://www.wttc.org/-/media/files/reports/economic-impact-research/regions2018/world2018.pdf (Accessed 2 February 2019).

Yousuf, M. and Backer, E. (2015), "A content analysis of Visiting Friends and Relatives (VFR) travel research", Journal of Hospitality and Tourism Management, Vol. 25, pp. 1-10. https://doi.org/10.1016/j.jhtm.2015.07.003.

Zátori, A., Michalkó, G., Nagy, J. T., Kulcsár, N. and Balizs, D. (2017), "The tourist experience of domestic VFR travellers: the case of Hungary", Current Issues in Tourism, pp. 1-23. https://doi.org/10.1080/13683500.2017.1371117.

Daniel Dragičević, $\mathrm{PhD}$, Assistant Professor

University of Rijeka

Faculty of Tourism and Hospitality Management

Department of Micro- and Macroeconomics

Primorska 42, P.P. 97, 51410 Opatija, Croatia

Phone: +38551294683

E-mail: danield@fthm.hr

Maja Nikšić Radić, PhD, Assistant Professor

University of Rijeka

Faculty of Tourism and Hospitality Management

Department of International Economics and Development

Primorska 42, P.P. 97, 51410 Opatija, Croatia

Phone: +38551294716

E-mail: majanr@fthm.hr

Suzana Herman, mag. oec., PhD student

University of Rijeka

Faculty of Tourism and Hospitality Management

Department for Knowledge Management

Livarska ulica 12, 1295 Ivančna Gorica, Slovenia

Phone: +385993040830

E-mail: sherman@bak.hr 